
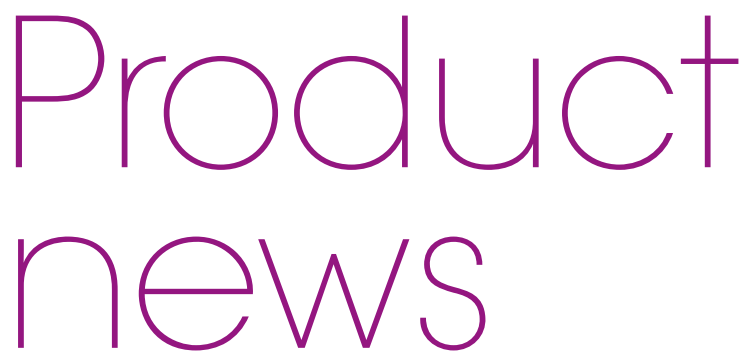

\section{ORTHODONTICS PRACTICE COMMIT TO REMOVING PLASTIC WASTE}

$\sin \theta$ $8 \theta$ she $e^{2}$

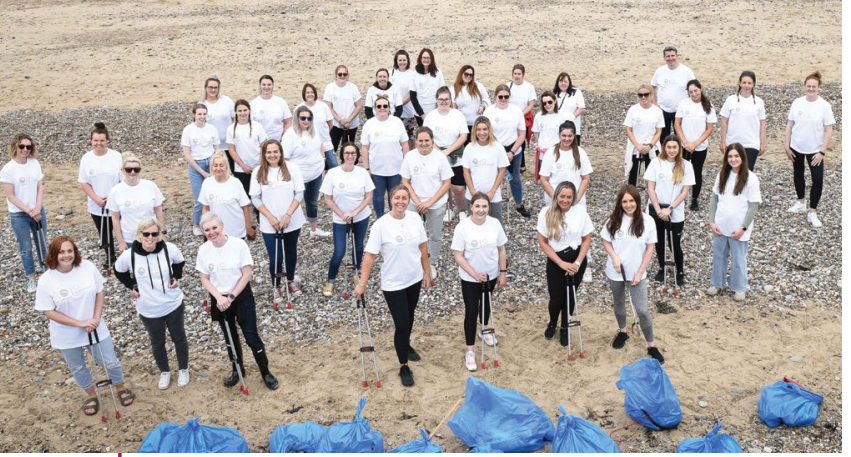

Queensway Orthodontics, which has five practices in the North-East, has committed to removing and recovering $30-40 \mathrm{~kg}$ of plastic waste.

By joining rePurpose Global's One for One Impact Guarantee Program, Queensway Orthodontics will fund the collection, processing, and reuse of 30-40 $\mathrm{kg}$ of ocean-bound plastic waste for every patient treated with clear, plastic aligners. In effect, Queensway Orthodontics is removing more ocean-bound plastic waste than it uses in its packaging, by reducing its own use of plastic and donating a percentage of every
Invisalign purchase to plastic reduction efforts.

Queensway Orthodontics are also working hard to eliminate or reduce plastic waste in the practice wherever possible, with zero-plastic, compostable or recyclable oral health products, including recycling Invisalign clear aligners.

In addition, Queensway Orthodontics - now a Dental CSR Certification - Gold Award company - organised a beach clean-up event to celebrate Plastic Free July and the whole team took part in the exciting initiative. The team collected rubbish from Seaham Beach on Friday 2 July, helping the local community, protecting the beautiful beach, and working with The Marine Conservation Society to gather data for the region. The team and their efforts meant they collected 11 bags of rubbish from the beach.

www.queenswayorthodontics.co.uk www.dentalcsr.co.uk

\title{
VISUALISE AND DIFFERENTIATE MINUTE DETAILS
}

Benefit from perfect clarity at first sight with the EyeMag Pro dental loupes supplied by Nuview. These loupes provide highcontrast stereoscopic images with edge-toedge sharpness, enabling you to visualise and differentiate minute details. Available in various magnification levels, EyeMag Pro loupes offer settings for a wide range of tilt and angle views, whilst facilitating a comfortable, ergonomic working position.

The EyeMag Pro can also be mounted on an adjustable headband or a lightweight titanium eyeglass frame, which can be fitted with prescription lenses at any time to further support the way you work. Contact Nuview to arrange a fitting.

For more information call Nuview on 01453 872266, email info@nuview-ltd.com or visit www.nuview.co.

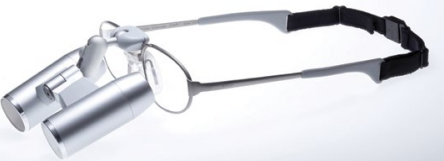

\section{A MUST VISIT FOR DENTAL HYGIENISTS AND THERAPISTS}

The British Society of Dental Hygiene and Therapy (BSDHT) is counting down the days until it can welcome delegates to this year's Oral Health Conference (OHC).

Taking place on 26-27 November at the SEC Glasgow, the $\mathrm{OHC}$ is the BSDHT's flagship event and a must visit for any dental hygienists, dental therapists and students of the profession. Offering an informative blend of topical seminars, hands-on product demonstrations and chances to network and socialise, the $\mathrm{OHC}$ encourages skill mix and gives professionals the opportunity to delve into topics and conversations that most interest them.

The perfect event to find tailored Enhanced CPD for the profession, the $\mathrm{OHC}$ also acts as a forum that gives a voice to people in the industry. Hear lectures from leading lights, take part in the conversation surrounding important aspects of your career - the $\mathrm{OHC}$ has something for everyone!

So, why not register today? Contact the BSDHT to find out more.

For more information about the BSDHT, visit www.bsdht.org.uk, call 01788 575050 or email enquiries@bsdht.org.uk.

\section{SEE 学ESEEN Putting the spotlight on dental hygienists \& dental therapists}

